Mr Dragan Dordevic, major, dipl. inž.

\section{Računar kao izvor zračenja}

\begin{abstract}
S obzirom na to da velika populacija ljudi u svom radu koristi računar, dakle uređaj koji za pogon koristi elektriěnu

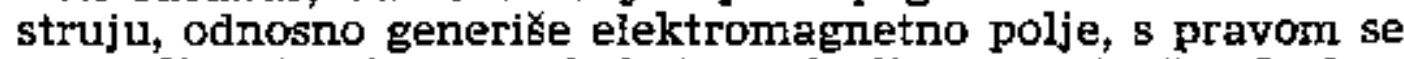
postavlja pitanje - u kakvim relacijama stoje čovek, kao korisnik, sa svojim bioenergetskim poljem i računar, kao sredstvo za rad, sa svojim elektromagnetskim poljem. Clanak nudi jasan pregled odnosa između čoveka i video-terminala, tako sto uzima u obzir: stetno zračenje monitora, zdravstvene uxinke u radu sa video-terminalom, ergonomske zahteve, kako video-terminala, tako i radnog mesta, kao i standarde pri radu sa video-terminalom.
\end{abstract}

\section{Uvod}

Sastavni deo sredine koja okružuje živi svet je prirodno zračenje. Covek se adaptirao na takvu sredinu koja ga okružuje i prema kojoj je formirao svoja čla. Razvoj civilizacije i tehnike sa svojim uređajima poremetio je prirodni ambijent, pa i ambijent u smislu zračenja talasa različitih talasnih dužina. Sigurno je da stalna aktivnost zračenja utiče na celokupni živi svet, pa i na ljudski rod. Pri povećanoj aktivnosti zračenja, odnosno pri povećanju jačine polja zračenja, sigurno je da dolazi do značajnih poremećaja funkcija organizma ili do stimulacije patoloskih procesa koji su započeli ranije.

Da bi se opasnost od primene zraCenja svela na razumne mere, neophodno je utvrditi doze iznad kojih taj poremećaj može izazvati privremeno ili trajno štetno dejstvo, kao i pratiti stepen ozračenosti ljudi od različitih vrsta zračenja i korelirati sa stepenom ozračenosti od prirodnog fona, za koji se može smatrati da je ljudski organizam uspostavio biološku ravnotežu.

Pojava računara i njihovih monitora, kao izvora zračenja, postavila je pred tehničke i medicinske stručnjake nove zahteve $u$ pogledu zaštite od zračenja, a sve radi očuvanja zdravlja lju- di, produženja njihovog radnog veka i postizanja optimalne produktivnosti rada.

\section{Štetno zračenje monitora}

U toku rada računara, oko monitora, kao njegove sastavne komponente, postoje polja različitog karaktera koja se u određenim uslovima mogu pokazati veoma štetnim. Poznavanje i sagledavanje pojava koje su prisutne u okruženju računara treba da predstavlja sastavni deo kulture rada sa uređajima računarske tehnike.

Radi sagledavanja ove problematike neophodno je poznavati način na koji se stvara slika na ekranu monitora, koji je veoma sličan načinu prikazivanja slike na kućnom televizoru. Izuzetak predstavljaju LCD i plazma-ekrani na laptop-računarima kod kojih je prikaz slike različit, a štetni uticaj daleko manji.

Katodna cev monitora u crno-beloj tehnici (monohromatskoj) radi sa anodnim naponom od $12-15 \mathrm{kV}$, dok katodne cevi u boji (polihromatski) sa naponom od oko $30 \mathrm{kV}$, što predstavlja dovoljan uslov za generisanje jonizujucég zračenja. Funkcija katodne cevi sastoji se $\mathrm{u}$ elektroluminiscenciji, tj. osobini fosfora da svetli pod uticajem elektronskog mlaza. Kao izvor elektronskog 
mlaza na poleđini monitora upotrebljen je elektronski top koji ispaljuje mlaz elektrona $\mathrm{ka}$ fosfornom premazu unutrašnje staklene površine ekrana. U momentu udara tačka na ekranu zasvetli određenim intenzitetom, da bi se posle izvesnog vremena ugasila. Međutim, sliku je potrebno održati na ekranu, pa se ovaj proces mora stalno ponavljati. Održavanje se vrši horizontalno od donjeg ka gornjem delu ekrana, a mlaz elektrona usmerava se delovanjem magnetnog polja. Kod polihromatskih katodnih cevi prisutna su tri mlaza, pa samim tim i tri zasebna magnetna polja, čime se povećava stepen zxačenja oko monitora.

Zračenje, kao poentu navedene problematike sa štetnim akcentom, najlakše je sagledati preko primarnih i sekundarnih štetnih faktora.

\section{Primarni štetni faktori}

Jonizujuće ili rendgensko zračenje može biti stetno u velikim dozama, ali ovde to nije slučaj. Ovo zračenje je nazvano »meko«, jer ima mali domet u vazduhu i prodornost $u$ materiju, tako da se, uglavnom, apsorbuje na staklu ekrana monitora. Ukoliko zračenje prelazi dozvoljeni nivo, razlog treba potražiti u visokonaponskom sistemu ili maloj gustini ekrana, što predstavlja omašku u proizvodnji. Još uvek ne postoje normativi za dozvoljeno X-zračenje monitora, pa su na snazi normativi koji se odnose na kolor katodne cevi televizora. Merenja su obavljena pod normalnim radnim uslovima na rastojanju od $5 \mathrm{~cm}$ od površine ekrana, a bili su obuhvaćeni prijemnici domaćih i stranih proizvođača. Ni u jednom slǔcaju nije bila registrovana jačina doze zračenja veća od dopuštene vrednosti. Međutim, ekspozicione doze zračenja zavise od primenjenog visokog napona, pa, ukoliko se visoki napon poveća iznad vrednosti radnog napona, ekspoziciona doza zračenja može preći dopuštenu vrednost od $0,036 \mathrm{nC} / \mathrm{kgs}$, odnosno $129 \mathrm{nC} / \mathrm{kgh}$.
Merenje je vršeno instrumentom Victoreen RF 440 u opsegu napona od $25 \mathrm{kV}$ do $32 \mathrm{kV}$, a dobijeni rezultati prikazani su grafikom na slici 1 .

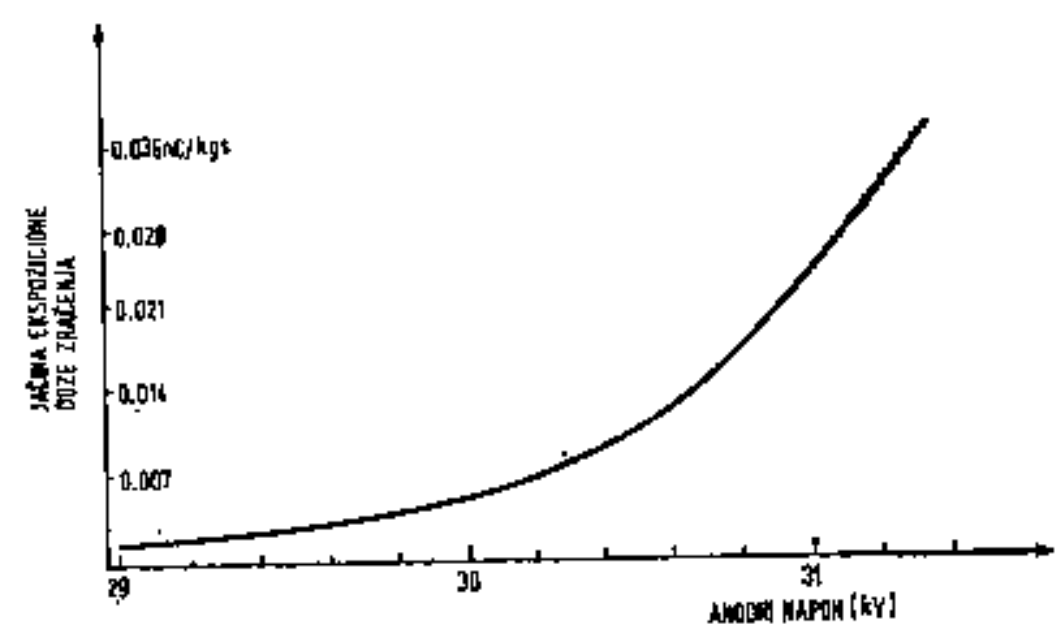

Sl. 1 - Promena jacine ekspozicione doze

Može se zaključiti da su doze X-zračenja iz monitora vrlo male i kreću se u opsegu oko $0,77 \mathrm{nC} / \mathrm{kgh}$, što je ispod prirodnog fona (oko $2,6 \mathrm{nC} / \mathrm{kgh}$ ), pa ovo zračenje ne predstavlja rizik po zdravlje operatora, pa čak i trudnica. Utvrđeno je da tokom rada i starenja ureảaja ne dolazi do povećanja ovog tipa zračenja.

Nejonizujuće zračenje sačinjava: ultraljubičasto, vidljivo $i$ infracrveno zračenje, zatim mikrotalasi, radio-talasi i elektromagnetno zračenje ekstremno niskih frekvencija.

Ultraljubičasto zračenje (10-400 $\mathrm{nm})$ uglavnom se deli na tri osnovne oblasti, po izrazito različitim biološkim efektima: UV-A talasnih dužina 400 do $320 \mathrm{~nm}$ (dugi UV talasi ili crno svetlo), UV-B od 320 do $280 \mathrm{~nm}$ (UV talasi ili „zraci za crnjenje«) i UV-C ad 280 do $200 \mathrm{~nm}$ (nazvani kratki UV talasi ili sterilizujuće zračenje). Talasne dužine kraće od $200 \mathrm{~nm}$ imaju malo značaja za biološke efekte, pošto zračenje u toj oblasti spektra (ekstremno ili vakum UV) biva apsorbovano na vrlo kratkom putu kroz vazduh. Rezultati merenja ultravioletnog zračenja, emitovanog sa ekrana monitora, talasne dužine 350 do $400 \mathrm{~nm}$ i na daljini $0,5 \mathrm{~m}$ od ekrana, uglavnom su se kretali od $0,2-12.9$ 
$\mathrm{mW} / \mathrm{m}^{2}$. Izmereni intenzitet zračenja, iako se apsorbuje u očnom tkivu, ispod je dozvoljenog nivoa koji iznosi 10 $\mathrm{W} / \mathrm{m}^{2}$. Treba napomenuti da se efekti UV zračenja, koji potiču od drugih izvora zračenja, a čiji je intenzitet znatno veći od dozvoljenog, ogledaju, uglavnom, na površinskim delovima organa vida: ivicama kapaka, vežnjači i rožnjači.

Vidljivo zračenje $(400-780 \mathrm{~nm})$, mereno u spektru talasnih dužina od 400 do $600 \mathrm{~nm}$, dalo je veoma niske vrednosti, tako da ne predstavlja opasnost koja bi se ogleđala u kratkotrajnom zaslepljenju oka.

Infracrveno (IC) zračenje (780-10 nm), mereno na ekranima monitora, nije se moglo detektovati. Međutim, ne treba isključiti mogućnost da ovaj tip zračenja može nastati i od drugih izvora u prostoriji u kojoj je lociran računar. Pored toga, monitori imaju snagu od 100 do $400 \mathrm{w}$, pa i oni mogu da zagreju rađnu prostoriju, što iziskuje potrebu za ventilacijom i stvaranjem optimalnih mikroklimatskih uslova za rad.

Elektromagnetno zračenje, opsega mikrotalasa ( $1 \mathrm{~mm}-1 \mathrm{~m}$ ) i radio-talasa $(1 \mathrm{~m}-10 \mathrm{~km})$, potiče od visokonaponskih transformatora i kalema za usmeravanje mlaza. Elektrostatičko polje najbolje se primećuje ako prstom dodirnemo prednju stranu monitora. Pucketanje koje se javlja pri dodiru mnogo je vece kod monitora u koloru i predstavlja prelazak naelektrisanja sa monitora na operatora i dalje, do zemlje.

$\mathrm{Za}$ frekventni opseg talasa od 10 $\mathrm{kHz}$ do $18 \mathrm{GHz}$ (od dugih radio-talasa do santimetarskih mikrotalasa) izmerena je jačina električnog polja od $11,87 \mathrm{x}$ $\mathrm{x} 10-4 \mathrm{~V} / \mathrm{m}$ do $3,68 \times 10-2 \mathrm{~V} / \mathrm{m}$, dok je za radio-frekventno područje od 10 $\mathrm{kHz}$ do $220 \mathrm{MHz}$ (dugi, srednji i kratki talasi) dobijena vrednost elektricnog polja od 1 do $5 \mathrm{~V} / \mathrm{m}$. Na daljini od 30 $\mathrm{cm}$ od monitora, u blizini transformatora i drugih izvora, lokalizovano je elektrostaticko polje jačine i $50 \mathrm{~V} / \mathrm{m}$ i magnetno $1,1 \mathrm{~A} / \mathrm{m}$, Kako je poznato da ovakve sile opadaju sa kvadratom rastojanja $\left(1 / \mathrm{r}^{2}\right)$, na radnoj udaljenosti od ekrana (slika 2) one su već znatno slabije, a sa upotrebom zaštitnih filtera mogu se efikasno umanjiti i time zaštititi operatora od neposrednog uticaja. Veći broj radova iz ove problematike navodi da na daljini $30 \mathrm{~cm}$ od ekrana, zračenje radio-talasa $(10 \mathrm{kHz}-10$ $\mathrm{MHz}$ ) ima jačinu električnog polja od 2,4 do $15 \mathrm{~V} / \mathrm{m}$, a jačinu magnetnog polja od 0,04 do $0,17 \mathrm{~A} / \mathrm{m}$.

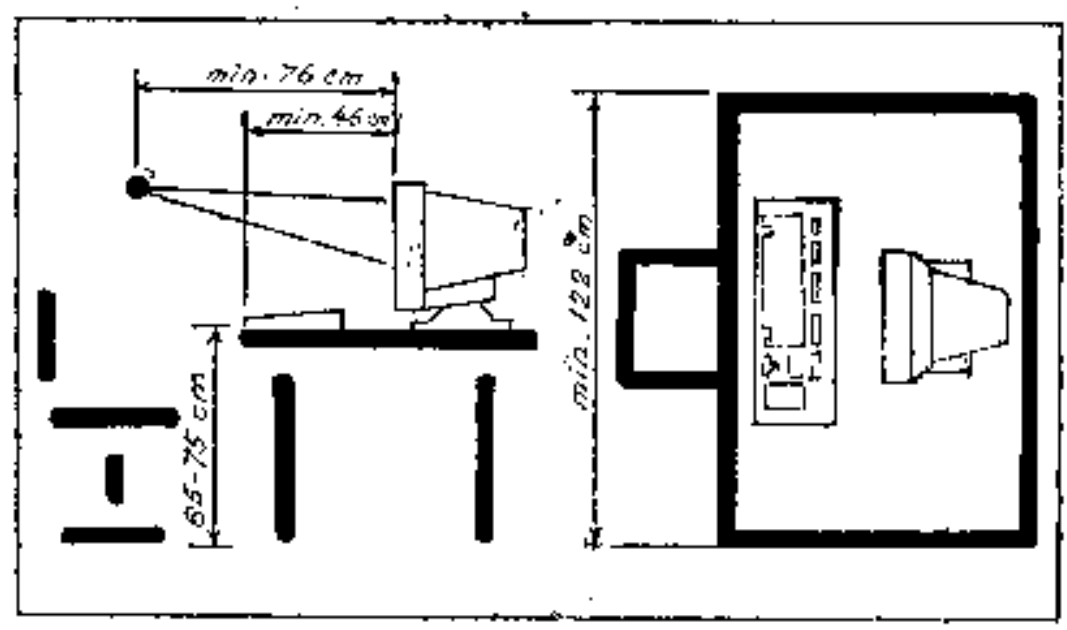

SL. 2 - Organizacija radnog mesta

Prema tome, utvrđeni nivo zračenja je manji od nivoa standarda za elektriéno (15-20 V/m) i magnetno (5$-10 \mathrm{~A} / \mathrm{m})$ polje i ne predstavlja neki rizik ukoliko se operator nalazi na propisanom rastojanju (slika 2) od monitora.

Kada se radi o niskofrekventrim elektromagnetnim poljima (ELF - Extremely Low Frequencies) 30 do 300 $\mathrm{Hz}$, a posebno onim ispod $100 \mathrm{~Hz}$, izmerene vrednosti za električno polje kreću se od $10 \mathrm{~V} / \mathrm{m}$, a magnetnog polja od $0,22-0,56 \mathrm{~A} / \mathrm{m}$ na $30 \mathrm{~cm}$ od ekrana monitora. Jača polja nađena su samo u blizini bočnih strana i pozadini uređaja. Zato su u pravu svi oni koji preporučuju rad sa računarom sa sigurne udaljenosti. Međutim, pored monitora i televizora, i kućanski aparati stvaraju elektromagnetna polja različite jačine. 
Jačina EM polja nekih aparata $z a$ domaćinstvo

\begin{tabular}{|l|c|}
\hline \multicolumn{1}{|c|}{ Aparat } & $\begin{array}{c}\text { Jacina EM polja (T) } \\
\text { ili }\left(10^{-6} \mathrm{~A} / \mathrm{m}\right)\end{array}$ \\
\hline Fen za kosil & $1000-2000$ \\
Usisivac & $200-1000$ \\
Mikser & $500-600$ \\
Elektriðni & $60-200$ \\
Sporet & \\
Televizor & $50-70$ \\
Frižider & $0,1-1$ \\
\hline
\end{tabular}

Vrednosti EM polja, iz tabele 1, mogle bi biti alarmantne bar na prvi pogled. Međutim, pogrešno bi bilo reći da je elektromagnetno polje oko monitora bezopasno u odnosu na polje oko fena, jer fen koristimo nekoliko minuta dok pred monitorom ostajemo celo radno vreme, nekada i duže. Pri tome nam je glava najizloženija izvoru polja, dok, na primer, uz sporet ne stojimo ceo dan.

\section{Sekundarni štetni faktori}

Statički elektricitet predstavlja naelektrisanje koje se stvara $u$ izolacionim materijalima pri trenju sa drugim predmetima, a koji se nalaze u prostoriji sa računarom. Nastaje pri sedenju i trenju na stolici koja je presvučena nekim sintetičkim materijalom. Na sintetičkim podovima pa i na vunerom tepihu u suvoj atmosferi, telo coveka može da se naelektriše običnim hodanjem po njima. U zagrejanim prostorijama, sa suvim vazduhom nastajanje statičkog elektriciteta je posebno indikativno.

Pri nastanku jakog statičkog naelektrisanja ,varnice mogu da pređu na korisnika. Pri radu sa knjigovodstvenim računarima izmerena je jačina električnog polja od 5000 do $10000 \mathrm{~V} / \mathrm{m}$, tako da je neprijatan osećaj pri malom »strujnom« udaru u toku pražnjenja ovog naelektrisanja. Zbog toga je ne- ophodno uvesti preventivne mere zaštite, koje se sastoje u održavanju dobrih mikroklimatskih uslova, stvaranju optimale vlažnosti u radnim prostorijama, kao i izolovanje računara i podova.

$B u k a$, koja se javlja u prostorijama pri radu računara, kreće se $u$ opsegu od $15 \mathrm{~Hz}$ do $20 \mathrm{~Hz}$, a nekada i opsegu ultrazvuka, $20-30 \mathrm{kHz}$. Nivo buke kreće se od 30 do $68 \mathrm{~dB}$. Ovi nivoi buke, po pravilu, ne oštećuju sluh, ali mogu da imaju ometajući karakter. $\mathrm{Ne}$ treba zaboraviti i ventilacione uređaje kao izvore buke. Utvrđeno je da dugotrajna i stalna buka smanjuje brzinu obrade podataka za 10 do $15 \%$. Zbog toga buka ne bi smela biti veća od $\mathbf{5 5}$ $\mathrm{dB}$ za poslove gde je neophodna visoka koncentracija, a $65 \mathrm{~dB}$ za rutinske poslove.

Poremećaj odnosa jona $u$ vazduhu predstavlja značajan faktor uticaja na organizam, pri radu sa računarom. Pod jonizacijom materijala podrazumeva se odvajanje elektrona iz njegovog atoma, pri čemu ostatak atoma postaje pozitivan. Ovaj elektron brzo se spaja sa drugim atomom, pri čemu on dobija negativan naboj. Ovakvi joni, ako ostanu samostalni, nazivaju se »laki« (n \pm ), a ukoliko se sjedine sa česticama magle, dima ili prašine, postaju krupni i nazivaju se »teški joni« $(\mathrm{N} \pm)$.

Stepen jonizacije vazduha obično se karakteriše brojem jona pozitivnog i negativnog znaka u jedinici zapremine $\left(\mathrm{m}^{3}\right)$. Higijensko stanje vazduha karakteriše broj lakih negativnih $(n-)$ ili pozitivnih $(n+)$ jona $u$ jedinici zapremine vazduha. Taj odnos izražava se preko količnika kancentracije pozitivnih i negativnih jona $u$ vazduhu, koji se naziva koeficijent unipolarnosti $q=$ $=n+/ n-$. Ne treba eliminisati ni znacaj koji ima odnos zbira teških prema zbiru lakih jona, koji se naziva »koeficijent zagađenosti atmosfere $=\mathrm{N} \pm / \mathrm{n} \pm$. Utvrđeno je da vazduh bogat negativnim lakim jonima utiče povoljno na organizam čoveka, povećava- 
jući koncentraciju hemoglobina, broja eritrocita, metabolizam, kao i raspoloženje za rad. Nasuprot tome, vazduh sa viškom pozitivnih jona pogoršava zdravstveno stanje i doprinosi porastu umo$\mathrm{ra}$, distoničnih smetnji, otežanog disanja, i dr. U atmosferi veštačke ventilacije vazduh sadrži veći broj pozitivnih teških jona, što negativno utiče na zdravlje i rad korisnika računara u takvim mikroklimatskim uslovima.

Bleštanje može biti direktno ili reflektujuće. To zavisi od boje zidova prom storije, nameštaja i izvora svetlosti. Za rad sa monitorima preporučuje se određen indeks bleštanja, koji treba da bude 16 za fini posao. Pojava refleksije od svetlosnih izvora i glatkih površina može mnogo da ometa rad korisnika. Sada se ekrani prave od stakla, koja su obrađena tako da ne daju refleksiju. Radi izbegavanja refleksije $i$ »zaslepljenja« operatora, potrebno je obezbediti organizacijske $\mathrm{i}$ ergonomske mere o kojima će biti reči u daljem tekstu.

Sjajnost simbola na ekranu mora da bude zadovoljavajuća, ali nikako da prouzrokuje bleštanje. Kontrast između simbola i stepena luminacije u pozadini nikako ne sme biti zapostavljen. Zbog kompenzacije jake svetlosti iz okoline korisnik često pojačava sjajnost, a to, pak, može da dovede do gubljenja rezoIucije i pojave efekta treptanja.

Frekvencija ili treperenje slike na ekranu monitora kreće se u rasponu od 25 do $60 \mathrm{~Hz}$. Sa povećanjem frekvencije smanjivace se napor $z a$ percepciju slike na monitoru, tako da se, pri frekvenciji od $100 \mathrm{~Hz}$, nece uočiti pojave treperenja. Optimalni odnos između dobre percepcije slike i trajnosti fosfora, kojim je prekrivena unutrašnja površina ekrana, postiže se primenom odgovarajućeg kvaliteta fosfora i frekvencije od $50 \mathrm{~Hz}$.

\section{Zdravstveni aučinci rada sa video-terminalom}

Povećanjem broja računara, a samim tim i broja korisnika, opravdano se postavlja pitanje rizika po zdravlje ljudi. Međutim, ne treba zapostaviti činjenicu da se zdravstveni ucinci mogu javiti ne samo kao posledica zračenja katodne cevi, već mogu nastati i kao rezultat neadekvatnih ergonomskih rešenja i loše organizacije rada sa video-terminalom.

Simptomi, koje zapažaju korisnici video-terminala, vezani su pre svega za organ vida (osećaj zamora, toplote, bola i refleksne smetnje). Pored ovoga, indicirani su i đrugi simptomi: glavobolja, opšti umor, depresija, tromost, razdražljivost, bolovi u kiěmi, rukama i dr.

Da li elektromagnetno zračenje koje generiše katodna cev ima uopšte kataraktogeni efekat? Rezultati kliničkih studija na ljudima nisu za sada ubedljivi i ne idu u prilog pozitivnom ili negativnom odgovoru. Mnogi smatraju da nema razlike u subjektivnim smetnjama, u odnosu na vrstu posla koji se obavlja na terminalima. Međutim, opisane su razlike u odnosu na vrstu posla prema polu operatora. Żene pate od smetnji vida dvostruko više nego muškarci. Razlike su naročito izražene pri radu na programiranju, gde $8,6 \%$ muškaraca i $23,4^{4} \%$ žena ima tegoba u obliku vidnog napora. $Z$ a pojavu smetnji u vidu operatora ima više razloga. Neki autori su kod operatora na unošenju podataka, u toku radnog dana, registrovali $8000-25000$ pokreta očiju između dokumenta i ekrana.

S obzirom na različitu osetljivost operatora, kao i na zahtev brzine i tačnosti posiova, postoje objektivni razlozi za povećanje vidnog napora.

Međutim, za dobro viđenje operator mora da ima dobar i korigovan vid, Podaci govore da jedna trećina zaposlenih ima nekorigovane vidne defekte, ne uzimajući u abzir da sposobnost fokusiranja opada sa godinama zbog prirodnog procesa starenja sočiva. Operatori treba da imaju odgovarajuće naočare. Bifokalne nisu pogodne, jer gornja stakla (za daljinu) ne odgovaraju za distancu od 0,5 do $0,7 \mathrm{~m}$ pri gledanju ek- 
rana, a donja (za blizinu) isto tako, jer su namenjena za čitanje.

$\mathrm{Na}$ grupi od 30 ispitanika, zaposlenih na video-terminalima, izvršen je detaljni medicinski pregled, pri čemu je opažen veliki broj graničnih elektroencelografskih rezultata, kao i oftalmološke promene. Okulisticki pregled sastojao se od pregleda: Javal, oštrine vida, reakcije zenica na svetlo, prosvetljavanja prozirnih medija paralaksom, snimanja prednjeg segmenta oka, očnog dna, i dr.

Rezultati (tabela 2) ukazuju na smanjenu oštrinu vida kod $40^{\omega} \%$ ispitanika, zamućenje sočiva kod $63,4 \%$ ispitanika, kao i promene krvnih sudova očnog dna kod $56,7^{10 / 0}$ ispitanika. njuktivita, osećaj bola i peska u očima, praćeni glavoboljama i mukom. Poteškoće $u$ percepciji dovodi do vizuelnih simptoma: nesposobnosti fokusiranja, viđenja obojenog ruba na objektu koji se posmatra, kao i nemogućnost gledanja $u$ jednom praveu tokom dužeg fiksiranja pogleda. Neki operatori su zabrinuti zbog ružičaste obojenosti pri gledanju belih predmeta, posle rada pred ekranima sa zelenim simbolima. Međutim, ova pojava, tzv. paslika, gde se ružičasto vidi kao komplementarna boja zelene boje na ekranu, bezopasna je i prolazna.

Zdravstveni učinci u ovoj maloj. grupi ispitanika opisani su bez rezultata prethodnih pregleda i bez moguć-

Rezultati oftalmoloskog pregleda

Tabela 2

\begin{tabular}{|c|c|c|c|c|c|c|c|c|c|c|c|c|c|c|}
\hline \multirow[t]{4}{*}{ Pol } & \multicolumn{4}{|c|}{ Oštrina vida } & \multicolumn{6}{|c|}{ Zamućenje sočiva } & \multirow{2}{*}{\multicolumn{4}{|c|}{$\begin{array}{l}\text { Oxno dno } \\
\text { Promene }\end{array}$}} \\
\hline & \multirow{2}{*}{\multicolumn{2}{|c|}{$\begin{array}{c}\text { Normal- } \\
\text { na }\end{array}$}} & \multirow{2}{*}{\multicolumn{2}{|c|}{$\underset{\text { na }}{\text { Smanje- }}$}} & \multirow{2}{*}{\multicolumn{2}{|c|}{ Nema }} & \multirow{2}{*}{\multicolumn{2}{|c|}{$\begin{array}{l}\text { Jedno } \\
\text { oko }\end{array}$}} & \multirow{2}{*}{\multicolumn{2}{|c|}{$\begin{array}{l}\text { Oba } \\
\text { oka }\end{array}$}} & & & & \\
\hline & & & & & & & & & & & & a & & ez \\
\hline & br. & $\%$ & br. & $\%$ & br. & $\%$ & br. & $\%$ & br. & $\%$ & br. & $\%$ & br. & $\%$ \\
\hline Muşkarci & $\mathbf{9}$ & 64,4 & 5 & 35,7 & 8 & 57,2 & 3 & 21,4 & 3 & 21,4 & 8 & 57,1 & 6 & 42,9 \\
\hline Zene & 9 & 56,2 & 7 & 43,8 & 3 & 18,8 & 8 & 50,0 & 5 & 31,2 & $\mathbf{5}$ & 31,2 & 11 & 69 \\
\hline Ukupno & 18 & 60,0 & 12 & 40 & 11 & 36,7 & 11 & 36,7 & 8 & 26,7 & 13 & 43,7 & 17 & 57 \\
\hline
\end{tabular}

Granični i promenjeni EEG rezultat ima $50^{6 / 0}$ ispitanika, $i$ to češće žene $\left(64,3^{0} \%\right)$ nego muškarci $\left(37,5^{0} \%\right)$.

Tabela 3

Rezultati elektroencelografskog snimanja

\begin{tabular}{|l|c|c|c|c|c|c|c|}
\hline $\begin{array}{c}\text { EEG re- } \\
\text { zultat } \\
\text { Pol }\end{array}$ & \multicolumn{2}{|c|}{$\begin{array}{c}\text { Nor- } \\
\text { malan }\end{array}$} & \multicolumn{2}{|c|}{$\begin{array}{c}\text { Grani- } \\
\text { can }\end{array}$} & \multicolumn{2}{|c|}{$\begin{array}{c}\text { Prome- } \\
\text { njenl }\end{array}$} \\
\cline { 1 - 5 } & br. & $\% \%$ & br. & $\% /$ & br. & $\% / 0$ \\
\hline Zene & 5 & 35,72 & 8 & 57,14 & 1 & 7,14 \\
\hline $\begin{array}{l}\text { Muš- } \\
\text { karci }\end{array}$ & 10 & 62,50 & 1 & 6,25 & 5 & 31,25 \\
\hline Ukupno & 15 & 50,0 & 9 & 30,0 & 6 & 20,0 \\
\hline
\end{tabular}

Najčešće smetnje koje navode korisnici su: iritacija, suvoća i pečenje ko- nosti upoređivanja sa odgovarajućom grupom. $\mathrm{Za}$ sada se ne mogu objasniti koji su od promenjenih rezultata, $\mathrm{i} u$ kojoj meri, uzrokovani nešto povećanim intenzitetom zračenja, ali rezultati izvrš̌enih studija, svakako, upućuju na dalj̄a istraživanja i trajni medicinski nadzor korisnika video-terminala.

Glavobolje, kao posledica vidnog napora, nemoguce je razlikovati od glavobolja koje su posledica napora muskulature vrata zbog lošeg položaja tela pri radu, ali se znatno može ublažiti izbegavanjem bleštanja i poboljšanjem opšteg osvetljenja. Pored toga, smanjena učestalost treperenja i suv vazduh mogu biti uzročnik nelagodnosti u očima, pa i glavobolje. 
Zbog treperenja ekranske sile može se provocirati posebna forma epilepsije. Međutim, pošto se radi o fotosenzitivnom obliku epilepsije, kao veoma retkom obliku epilepsije, neopravdano je sve osobe sa dijagnozom epilepsije isključiti iz rada sa video-terminalom.

Promene na koži u vidu eritema na licu i vratu mogu se javiti nakon 2-5 časova rada na video-terminalima. U većini slučajeva, sledećih dana, koža je normalna, pa se zalključuje da je profesionalni kontaktni dermatitis bio prouzrokovan submikroskopski precipitira jućim česticama prašine na koži operatora, koje je akumulirao statički elektricitet. Pri povećanju relativne vlažnosti vazduha i smanjenju statičkog elektriciteta u radnim prostorijama, navedeni problem bio bi pozitivno rešen.

Zabeležen je i uticaj monitora, tj. niskofrekventnog magnetnog polja na amalgamske zubne plombe. Poznato je da se $50 \%$ žive i $35 \%$ srebra nalazi u amalgansikim plombama, pa, kao takve, provode struju što za posledicu ima izdvajanje žive u ustima operatora. Dozvoljena koncentracija žive $\mathrm{u} \mathrm{kr-}$ vi je do $5 \mathrm{mg}$ po litru. Ako znamo da prisustvo jedne amalgamske plombe povećava koncentraciju žive za $0,5-2,0$ $\mathrm{mg}$ po litru, a sedenje uz video-terminal može da podigne koncentraciju i do $50 \mathrm{mg}$ po litru, onda možemo i pretpostaviti kakav je indirektni uticaj monitora na sastav krvi coveka. Pomenuti uticaj znatno se umanjuje ne samo zamenom amalgamskih plombi već i zamenom "faze $i$,nule « na kablu kojim se napaja monitor, uz otvoreno pitanje gde nabaviti instrument kojim se proverava ponašanje monitora.

Smetnje koje se odnose na preopterécenost mišićno-koštanog sistema (bol i ukočenost vrata $i$ ramena, otečenost mišića i zglobova) po intenzitetu se ne razlikuju od onih koje se javljaju kod ostalih zanimanja koje se obavljaju u sedećem položaju. Problem se može znatno umanjiti obezbeđivanjem prifikladnih stolica, kao i povremenim menjanjem radnih zadataka uz fizičku poknetljivost $u$ toku rada.

Pojava defektno rodene dece i broja spontanih abortusa, prema kanadskim i američkim istraživanjima, ne dovodi se $u$ vezu sa korišćenjem video-terminala, jer se pomenute pojave ne razlikuju od opšte populacije. Međutim, ovaj problem zahteva dalja istraživanja.

Nova profesionaIna aktivnost, rad sa računarom, donosi i psihicke probleme. Zahtev za povećanom pažnjom i značajno ogranicenje socijalnih kontakata mogu izazvati potpuno različite reakcije kod više ljudi, što zavisi od individualnih sklonosti. Rad sa monitorom nije direktni uzročnik stresa, ali stepen stresnih reakcija proporcionalan je tempu rada, stepenu odgovornosti, individualnoj motivaciji, načinu uvođenja promena, kao i prihvatanju nove. tehnologije.

Pomenuta lista kontraindikacija za rad sa video-terminalima nije konačna, ali se uočava koje osobe ne bi trebalo da rade sa vioe-terminalima uz stalnu kontrolu potencijalnih štetnih faktora kako bi se sačuvalo zdravstveno stanje korisnika, a samim tim i produktivnost rada.

\section{Ergonomski zahtevi video-terminala i radnog mesta}

Radi postizanja optimalne produktivnosti rada i čuvanja zdravstvenog stanja korisnika mora se voditi racuna o ergonomskom prilagođavanju video-terminala, kao i radnog mesta, potrebama čoveka.

Ekran monitora može biti izveden sa: katodnom cevi, tečnim kristalom, plazmom i elektroluminiscencijom. Međutim, svaki od navedenih tipova ekrana ima svoje prednosti i nedostatke u odnosu na korisnika. Uočljivost simbola i jasnoća slika na ekranu zavise od više faiktora: rezolucije, boje, kontra- 
sta, polariteta displeja, luminiscencije, i dr. Minimalna površina matriène tačke treba da iznosi $5 \times 7$ ili $7 \times 9$. To znači da za matricu veličine $5 \times 7$ veliko slovo treba da bude široko 5 tačaka, a visoko 7. Pored toga, zbog nagiba, potrebne su dve tačke za razmak između slova. Međutim, rezolucija veca od $9 \times 11$ manje utiče na čitlijivost ad oblika tacaka. Pravougle i četvrtaste tačke ispunjavaju veću površinu između tacaka, pa su zbog toga bolje od kružnih.

Kontrast između simbola i stepena luminacije pozadine vrlo je važan faktor kvaliteta slike. Citliivost simbola može se povećati najviše do nivoa odnosa luminacije pozadine od 40:1. Međutim, anketa korisnika dala je rezultate koji su potvrđivali vrednost između $8: 1$ do $12: 1$, što nas navodi na zaključak da su najbolij oni terminali koji imaiu moguénost podešavanja kontrasta i boje podloge.

Za dobro opažanje bez zamora i udoban rad veoma je važan izbor boje simbola i pozadine na ekranu. Naiveću osetlïivost na monohromatske boje i vidni konfor pružaju crni simboli na svetloj pozadini. Međutim, osetljivost na svetlucanie i treperenje simbola najveća je na ekranima sa tamnim simbolima, pa je potrebno naći nekakav kompromis. Utvrđeno je. isto tako, da simboli ne bi trebalo da budu u zelenoj ili plavoj boji.

Izbor tastature, takođe. predstavlia važan ergonomski zahtev. Danas ie tržište preplavlieno različitim vrstama tastature čiji se raspored slova razlikuje od klasičnog »OWERTY« standarda za visace mašine, na koji je najveći broj liudi navikao. Površina dirke treba da se kreeć u granicama od 10 do $19 \mathrm{~mm}^{2}$, dok ie optimalna površina $13 \mathrm{~mm}^{2}$. Oblik dirke treba da bude kvadratni i maIo udublien, dok razmak između niih treba da bude $6 \mathrm{~mm}$. Solidna tastatura mora da ima i regulisanu osetliivost nk nritisak. Dri čemu se ta sila krése od 0,25 do 0,5 N. Ukoliko su dirke meke ili tvrde, povećava se verovatnoća greške. Ne treba izostaviti ni nagib tastature u odnosu na površinu stola koji treba da bude $5-10$ i srednja visina oko $30 \mathrm{~mm}$.

Mnogobrcjni su i ergonomski zahtevi koji se tiču radnog mesta korisnika. Temperatura vazduha prostorije treba da bude $19-23^{\circ} \mathrm{C}$, relativna vlažnost $10-60 \%$, ali nikako ispod $40 \%$. $\mathrm{Da}$ bi smanjili opterecenje motornih i senzornih funkcija korisnika, neophodno je obezbediti dovoljan prostor za rad. Smatra se da optimalni prostor ok ko korisnika treba da iznosi $1,5 \mathrm{~m}$ poluprečnika. Isto tako, radno mesto korisnika treba da se nalazi $1 \mathrm{~m}$ od bočne i zadnje strane monitora susednih radnih mesta. Radno mesto treba da bude projektovano tako da omoguava lakk promenu položaja tela, čime se masira diskus kičme, i otklanjaju zdravstveni problemi.

Sto, ukoliko postoji mogućnost podešavanja visine, treba da ima visinu od 65 do $75 \mathrm{~cm}$. Za filksme stolove preporuluje se visina od $70 \mathrm{~cm}$. Kada se video-terminal koristi povremeno preporučuje se visina stola od 90 do 115 cm.

Stolica, dobrog kvaliteta, mora da ima visinu koja se podešava kao i naslon za leđa. Najbolje su podešavajuće stolice sa pet nogu. Visina stolica kreće se u opsegu $40-50 \mathrm{~cm}$, dok sedeća površsina ne sme biti uža od $40 \mathrm{~cm}$. NasIon za leđa treba da bude zakrivljen i da ima oslonac za leđa širine oko 13 $\mathrm{cm}$ i visine od 15 do $28 \mathrm{~cm}$. Naslon za ruke nije neophodan, dok ugao kolena treba da bude veći od $90^{\circ}$. Ugao glave treba da bude oko 20 prema inklinaciji, a daljina očiju oko $0,75 \mathrm{~m}$. Prema tome, najbolji su oni računari koji imaju odvojenu tastauru od monitora, a monitor ima mogunost podešavanja ugla.

$\mathrm{U}$ ergonomske zahteve radnog mesta spada $\mathrm{i}$ dobro izvedena ventilacija. Pored prirodne (vrata i prozori), neka- 
da je neophodno izvesti i veštačku (ventilatore), namenjenu za ubacivanje svežeg ili odvod zagađenog vazduha. Treba imati na umu da ventilacija mora biti dobro urađena kako se ne bi remetio odnos pozitivnih $i$ negativnih jona, kao i gomilala prašina i toksične materije u radnoj prostoriji. Postavljanje ventilacionih uređaja je veoma kompleksan zadatak i zahteva timski rad, kako tehničkih, tako i medicinskih stručnjaka za svaku prostoriju posebno, tj. radno mesto. Ovaj zahtev dolazi naročito do izražaja kod prostorija sa vecim brojem korisnika (biroa, učinioca, i dr.).

$\mathrm{Ne}$ treba zapostaviti ni osvetljenje prostorija koje mora biti difuzno kako bi se, istovremeno, radilo i sa ekranom i sa pisanim dokumentima. Za radnu prostoriju preporučuje se osvetljenost od $1501 \times$, a za radnu povrsinu $5001 \times$. Direktno ili indirektno bleštenje od izvora svetlosti u prostoriji može se ublažiti oblaganjem radnih površina i zidova materijalima koje ne reflektuju svetlost.

Odmoru korisnika, isto tako, treba posvetiti posebnu pažnju. Posle dva sata neprekidnog rada potrebno je napraviti pauzu radi odmora očiju i mišća pod tenzijom. Odmor treba da bude van radnog mesta. Zbog svih ovih razloga korisnicima treba omoguićti da aktivno uzmu udela $u$ organizaciji uređenja i opremanja radnih mesta i prostorija za rad.

\section{Standardi pri radu sa videot-terminalom}

U svetu je zastupljen veoma širok spektar standarda. Evropski se, uglavnom, odnose na vizuelnu ergonomiju, a američki regulišu više opasnosti od zra«enja. Najpotpunije usvojeni standard ima američka armija koja daje humane i tehničke kriterijume za projektovanje video-terminala, uslove rada i opreme. $\mathrm{Na}$ području Evrope najkompletniji standard postavili su Śveđani, kao rezultat dugotrajnog ispitivanja. Za sada, naša zemlja ne poseduje kompletan standard, ali je utešno da stručnjaci profila tehničke i medicinske struke rade na tome.

\section{Zaključak}

Radi smanjenja štetnog uticaja monitora na zdravlje čoveka veoma je važno ne samo pravilno odabrati monitor i zaštitin filter, nego ga i pravilno locirati u radnoj prostoriji. Ukoliko je monitor jeftiniji i sastavne komponente su manje kvalitetne, pa je, stoga, i zračenje veće. Pravilnim izborom materijala za konstrukciju katodne cevi i filtera znatno se povećava zaštita. Međutim, s pravom se postavlja pitanje koliko je i filter efikasan kada znamo da monitor zrači na sve strane, a da se filter monitora na prednjoj strani ekrana i da štiti samo delove glave. No, kakav filter kupiti? Cene su im veoma različite i kré́u se od 30 do 300 DEM. Od jeftinijih može se očekivati samo poveanje kontrasta slike i smanjenje refleksije svetla, dok nas oni sa većom cenom mogu delotvorno zaštititi: povećanjem kontrasta, smanjenjem odbleska i distorzije slike, umanjenjem treptaja, eliminisanjem statičkog polja i smanjenjem ultravioletnog i X-zračenja, kao i umanjenjem elektromagnetnog polja. Međutim, sa povećanjem broja zaštitnih vlakana u filteru, slika bi bila isuviše zatamljena, što bi zahtevalo dodatni napor pri radu. Zato treba pronaći kompromis, između cene korištenja i ponude naših trgovaca. Pri kupovini treba obratiti pažnju i kupiti filiter koji ima provodnik za odvođenje statickog elektriciteta.

Pravilno odabrana pozicija računara, ili više njih u radnoj prostoriji, nije od male važnosti. Treba obratiti pažnju i na raspored monitora u susednim prostorijama. Imajući na umu da monitor zrači najviše sa zadnje strane, 
elektromagnetno polje neće biti zaustavljeno jednim običnim pregradnim zidom, jer je za to potrebno mnogo više. Zato, ako se monitori nalaze neposredno pored zida treba paziti da se sa druge strane nalazi radno mesto. Treba voditi računa o rastojanju koje postoji od poleđine monitora do susednog korisnika. Jedna od mogunosti prikazana je na slici 3 .

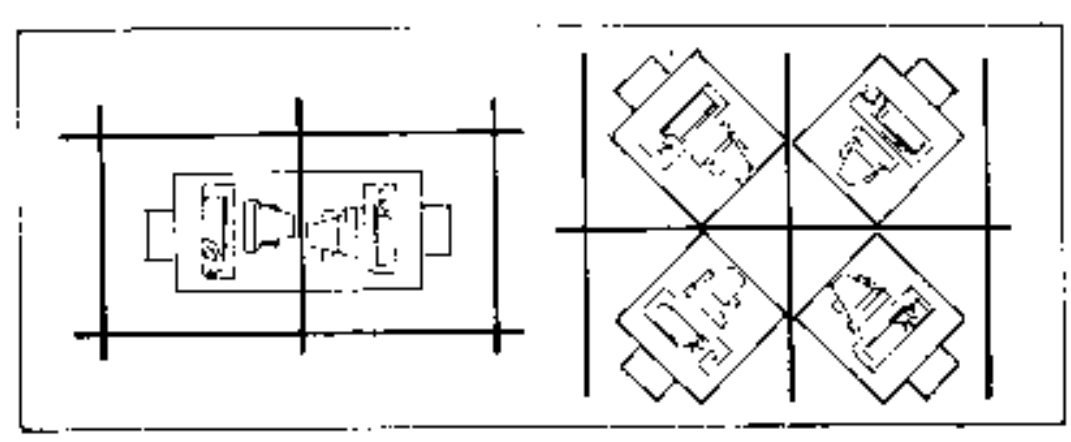

Sl. 3

No, bez obzira na to kakvim video-terminalom raspolažemo i koliko vremena provodimo u radu sa njim, trebalo bi imati na umu nekoliko praktjčnih saveta:

- pri kupovini monitora obratiti pažnju na monitore sa oznakom Low Radiation. Ovi monitori su specijalno obloženi iznutra sa svih strana, pa se najveći deo električnih polja apsorbuje. $\mathrm{Uz}$ njih se dobija sertifikat izvršenih merenja koji garantuju zračenje ispog granica;

- ako niste $u$ mogućnosti da kupite monitor sa pomenutom oznakom, on-

Literatura:

[1] Zbornik radova, XIV Iugoslovengki simpozijum zastite od zračenja, Novi Sad, juni 1987.

[2] Goldonx J., Sariç A., Zbornik radova, Zdravstveni učinet rada s video-terminalima, Instîtut za medicfnu rada, Zagreb, 1987.

[3] Tomašević M., Košutić D, Zbornlk radova, Institut za mediclinu rada i radiolórku zaštitu, Beograd, 1997. da izaberite ekran sa nerefleksnim staklom, pri čemu treba izbeći odblesak od prozora ili kakvog izvora veštačke svetlosti;

- ekran držati 10 do 15 stepeni niže od visine očiju u sedećem položaju;

- dokumente koje koristite u radu držite bliže ekranu i na istoj visini, kako se ne bi menjao fokus oka u toku rada;

- u toku rada treba češce skretati pogled sa ekrana, kako bismo odmarali oči;

- na svakih sat-dva rada treba napraviti pauzu od 15 minuta i to, po mogućnosti, van radne prostorije.

Pored činjenice da su računarski sistemi zauzeli svoje mesto u savremenom društvu, očigledno je da su se pojavili sasvim novi zahtevi na radnom mestu u pogledu povećane koncentracije i pažnje korisnika. Evidentirane zdravstveni učinci koji se javljaju pri radu sa video-terminalom nisu samo posłledica zračenja, zbog neadekvatno konstruisanog monitora, već i nepovoljno postavljenih ergonomskih uslova radnog mesta. U svetu još uvek ne postoje jedinstveni kriterijumi koji definišu konstruktivne i ergonomske zahteve za rad sa video-terminalima i skoro svaka zemlja ima svoje norme ili ih uopšte nema, kao što je to slučaj sa našom zemljom. To navodi na zaključak da je za rešavanje ovog problema neophodno timsko angažovanje, kako tehničkih, tako i medicinskih stručnjaka.

[4] Obrovaðki Ivan, Svet kompjutera, maj 1992.

[5] Tomăšvic Mirosiav, Kontrola X-zracenja kod TV-prijemnika, Jugoslovenski simpozijum o zastiti od zracerja, 1981.

[6] Milicević Slobodan, Neki ergonomski 1 medicinski problemt pri radu sa video-terminalima, Praksa, 1990. 